DOI: https://doi.org/10.24127/ajpm.v8i3.2360

\title{
PENGEMBANGAN LEMBAR KERJA SISWA BERBASIS PROBLEM BASED LEARNING PADA MATERI BANGUN RUANG SISI DATAR
}

\author{
Lahirna Dwi Agitsna $^{1}$, Reny Wahyuni ${ }^{2 *}$, Drajat Friansah ${ }^{3}$ \\ ${ }_{1,2,3}$ Pendidikan Matematika, STKIP PGRI Lubuklinggau \\ *Corresponding author. Address: Department of Mathematics Education, STKIP PGRI Lubuklinggau, 31625, \\ South Sumatera, Indonesia.

E-mail: $\quad \frac{\text { lahirna.dwiagitsna@gmail.com }}{{ }^{1)}}$

Received 3 October 2019; Received in revised form 6 December 2019; Accepted 24 December 2019

\begin{abstract}
Abstrak
Penelitian ini bertujuan untuk mengembangkan bahan ajar berupa Lembar Kerja Siswa Berbasis Problem Based Learning pada materi bangun ruang sisi datar dan untuk mengetahui kualitas lembar kerja siswa (LKS) dilihat dari aspek kevalidan dan kepraktisan. Penelitian ini merupakan penelitian pengembangan yang mengacu pada model pengembangan ADDIE, yaitu analisis, perancangan, pengembangan, implementasi dan evaluasi. Subjek dalam penelitian ini adalah siswa kelas VIII SMP Negeri 11 Lubuklinggau. Instrumen yang digunakan untuk mengukur kualitas LKS yang dikembangkan meliputi angket ahli dan angket kepraktisan siswa. Angket ahli digunakan untuk mengukur kevalidan LKS sedangkan angket kepraktisan siswa digunakan untuk mengukur kepraktisan LKS. Produk penelitian berupa Lembar Kerja Siswa Berbasis Problem Based Learning $(P B L)$ pada materi bangun ruang sisi datar kelas VIII SMP. Hasil penelitian menunjukkan bahwa kualitas bahan ajar dilihat dari aspek kevalidan termasuk dalam kategori valid dengan skor rata-rata 3,08 berdasarkan penilaian tiga dosen ahli (ahli bahasa, materi dan media) dengan skor maksimal 4,00; dan kualitas bahan ajar dilihat dari aspek kepraktisan dikategorikan praktis dengan skor rata-rata 3,40 berdasarkan hasil respon siswa terhadap LKS.
\end{abstract}

Kata kunci: Bangun ruang sisi datar, problem based learning, $R \& D$.

\begin{abstract}
This study aims to develop teaching materials in the form of Problem Based Learning Based Worksheets on the material to construct solid geometry and to determine the quality of student worksheet seen from the aspects of validity and practicality. This research is a development research that refers to the ADDIE development model, namely analysis, design, development, implementation and evaluation. The subjects in this study were eighth grade students of SMP Negeri 11 Lubuklinggau. The instruments were used to measure the quality of worksheets developed include expert questionnaires and student practicality questionnaires. Expert questionnaires were used to measure the validity of student worksheet while the student practicality questionnaire was used to measure the practicality of student worksheet. The research products are in the form of Problem Based Learning Based Student Worksheets in the VIII grade solid geometry material. The results of the study show that the quality of teaching materials seen from the validity aspect is included in the valid category with an average score of 3.08 based on the assessment of three expert lecturers (linguists, material and media) with a maximum score of 4.00; and the quality of teaching materials seen from the practicality aspect is categorized as practical with an average score of 3.40 based on the results of student responses to student worksheet.
\end{abstract}

Keywords: Problem based learning; R\&D; solid geometry.

\section{PENDAHULUAN}

Titik berat kurikulum 2013 (Anwar, 2014) bertujuan untuk mendorong siswa agar mampu lebih baik dalam melakukan observasi, bertanya dan mengkomunikasikan (mempresentasikan) yang mereka peroleh atau mereka ketahui setelah menerima materi pembelajaran di sekolah. Mengoptimalkan peran guru 
dalam pembelajaran yaitu sebagai sumber belajar, fasilitator, pengelola, demonstrator, pembimbing, motivator, dan evaluator (Alawiyah, 2013). Sebagai fasilitator, guru dapat mengembangkan berbagai cara untuk memudahkan siswa dalam proses pembelajaran.

Salah satu caranya adalah mengembangkan lembar kerja siswa sesuai kebutuhan siswa. Ada banyak penelitian yang terkait pengembangan bahan ajar ataupun lembar kerja, seperti penelitian yang dilakukan oleh Zulfah (2017) tentang pengembangan lembar kerja berbasis Problem Based Learning $(P B L)$ pada materi sistem persamaan linier dua variabel (SPLDV) dan Teorema Pythagoras kelas VIII SMP. Akan tetapi LKS yang dikembangkan baru mencapai tahapan Preliminary Research. Pembelajaran menggunakan LKS berbasis $P B L$ dapat membantu proses pembelajaran, menyajikan permasalahan yang harus dipecahkan bersama sehingga terciptanya kegiatan pembelajaran yang mampu melatih kemampuan memecahkan masalah dan dapat meningkatkan kerjasama dan tanggung jawab siswa dalam menemukan konsep (Wasonowati, Redjeki, \& Ariani, 2014). Selain itu, ada juga penelitian mengenai pengembangan LKS berdasarkan model pembelajaran guided discovery (Saraswati \& Nuryani, 2018).

Dari beberapa penelitian tersebut, belum ada yang mengembangkan LKS berbasis problem based learning (PBL) pada materi bangun ruang sisi datar. Hal ini diperkuat dari hasil observasi di SMP Negeri 11 Lubuklinggau diketahui bahwa bahan ajar dan lembar kerja yang digunakan hanya berasal dari buku paket dan LKS dari penerbit tertentu yang isinya terlalu singkat. Hal ini menjadikan pelajaran matematika merupakan mata pelajaran yang sulit dipelajari oleh siswa, dengan adanya hal ini menyebabkan ketuntasan hasil belajar siswa di bawah rata-rata.

Salah satu faktor penyebab masalah di atas yaitu kurangnya kreativitas guru dalam memanfaatkan bahan ajar ataupun lembar kerja yang sesuai kebutuhan siswa. Oleh karena itu, perlu adanya inovasi penggunaan lembar kerja yang digunakan di kelas dan sesuai dengan tuntutan kurikulum yang berlaku, sehingga siswa lebih kritis dalam memecahkan masalah matematika. Pembelajaran matematika yang aktif, kreatif, efektif dan menyenangkan merupakan suatu pembelajaran yang diharapkan oleh siswa, sehingga pembelajaran di kelas dapat terlaksana dengan baik (Wahyuni \& Efuansyah, 2018).

Hal ini sesuai dengan karakteristik Problem Based Learning yaitu sebagai suatu model pembelajaran konstruktivistik berorientasi pada student centered learning yang mampu menumbuhkan jiwa kreatif, kolaboratif, berpikir metakognisi, mengembangkan kemampuan berpikir tingkat tinggi, meningkatkan pemahaman akan makna, meningkatkan kemandirian, memfasilitasi pemecahan masalah, dan membangun teamwork (Sofyan \& Komariah, 2016). Selanjutnya untuk materi bangun ruang sisi datar dapat disajikan dengan menggunakan model pembelajaran Problem Based Learning, karena model $P B L$ menyajikan masalah secara kontekstual dan dapat membuat siswa menyimpulkan atau menyelesaikan masalah yang berhubungan dengan kehidupan seharihari yang dialami siswa.

Hal lain terkait pada proses pembelajaran di SMP Negeri 11 Lubuklinggau adalah guru belum 
mampu membuat sendiri bahan ajar yang sesuai dengan kurikulum dan tuntutan perkembangan zaman. Guru belum mengembangkan LKS sebagai bahan mengajar yang mampu menyajikan materi secara rinci, memuat banyak soal dan masih menggunakan LKS yang siap pakai. Pentingnya mengembangkan media pembelajaran menjadi salah satu faktor penentuan keberhasilan dalam mencapai tujuan pembelajaran yang telah ditentukan. Sebagaimana yang diungkapkan oleh (Nasution, 2016) bahwa bahan ajar sangat penting artinya bagi guru dan siswa, guru akan mengalami kesulitan dalam meningkatkan hasil dan mutu pembelajaran jika tanpa disertai bahan ajar yang lengkap. Bahan ajar mempunyai jenis seperti bahan ajar visual, yang terdiri dari buku ajar, handout, modul, lembar kerja siswa, gambar, brosur, dan lain sebagainya. Ada pula bahan ajar interaktif, seperti bahan ajar berbasis web, dan aplikasi pembelajaran interaktif (Setiawan \& Wariin B, 2017).

Untuk menyelesaikan masalah tersebut yaitu mengembangkan Lembar Kerja Siswa (LKS) karena LKS dapat memudahkan guru maupun siswa dalam mengerjakan tugas-tugas suatu pokok bahasan berisi informasi pendukung, latihan-latihan yang harus dikerjakan oleh siswa dalam suatu konsep pokok bahasan yang terdapat dalam kurikulum yang disusun guru (Ermi, 2017). Dalam LKS siswa akan mendapatkan materi, ringkasan, tugas yang berkaitan dengan materi dan terdapat arahan untuk memahami materi yang diberikan serta terdapat tempat untuk menuliskan jawaban, hal ini akan membuat siswa belajar mandiri dan mempermudah proses pembelajaran (Jayanti \& Wiratomo, 2017). Pengembangan LKS pada saat ini baru sebatas latihan soal dan belum dapat menjadi bahan ajar yang mampu meningkatkan pemahaman konsep (Saraswati \& Nuryani, 2018). Pembelajaran $P B L$ dapat sesuai dengan langkah-langkah yang sistematis dan terstruktur salah satu media yang dapat digunakan adalah Lembar Kerja Siswa. Hal ini sesuai dengan pengertian LKS, yaitu lembaran-lembaran yang berisi informasi dan instruksi untuk mengerjakan suatu kegiatan belajar (Ernawati, Ibrahim, \& Afiif, 2017).

Pengembangan LKS berbasis $P B L$ menghubungkan materi pembelajaran bangun ruang sisi datar dengan permasalahan yang nyata dapat mempermudah proses pembelajaran dengan menghadirkan gambar dan bentuk visual secara kontekstual. Oleh karena itu, tujuan dari penelitian ini adalah menghasilkan lembar kerja siswa berbasis Problem Based Learning pada materi bangun ruang sisi datar kelas yang valid dan praktis.

\section{METODE PENELITIAN}

Penelitian ini menggunakan metode Research and Development (R\&D) dan menghasilkan produk bahan ajar berupa Lembar Kerja Siswa dengan menggunakan model Problem Based Learning tentang materi bangun ruang sisi datar di SMP Negeri 11 Lubuklinggau. Adapun desain dan pengembangan LKS menggunakan model pengembangan ADDIE yang terdiri atas 5 tahapan yaitu: Analysis (analisis), Design (desain), dan Development (pengembangan), Implementation (implementasi) dan Evaluation (evaluasi).

Tahap Analysis; dilaksanakan analisis kebutuhan, analisis kompetensi dan instruksional.

Tahap Design; dalam tahap ini kegiatannya adalah menentukan proses 
yang sistematik dimulai dari menetapkan tujuan pembelajaran, skenario pembelajaran, merancang perangkat pembelajaran, merancang materi pembelajaran dan alat evaluasi hasil belajar.

Tahap Development; pada tahap ini berisikan kegiatan realisasi rancangan produk. Dalam tahap desain, telah disusun kerangka konseptual penerapan model/metode pembelajaran baru. Tahap pengembangan ini juga dilakukan pengumpulan materi, penggarapan atau pembuatan, pengujian dan distribusi, pengembangan instrumen evaluasi produk, melalui evaluasi ahli isi, media dan desain pembelajaran, perbaikan produk berdasarkan pendapat dan saran dari para ahli. Setelah melalui tahap tersebut barulah dapat dilakukan uji coba kelompok kecil.

Tahap Implementation; tahap ini meliputi uji coba kelompok besar.

Tahap Evaluation; dilakukan dalam dua bentuk yaitu evaluasi formatif dan sumatif. Evaluation formatif dilaksanakan pada setiap akhir tatap muka, sedangkan evaluation sumatif dilakukan setelah kegiatan berakhir secara keseluruhan.

Penelitian dilaksanakan menggunakan angket. Angket yang digunakan untuk menilai kevalidan dan kepraktisan LKS yang telah dikembangkan. Untuk validator para ahli terdiri dari ahli bahasa, ahli materi dan ahli media yang merupakan dosen STKIP PGRI lubuklinggau. Uji coba kelompok kecil dilakukan oleh 6 siswa yang dipilih secara heterogen yaitu siswa yang memiliki kemampuan tinggi, sedang dan rendah, sedangkan uji coba kelompok besar dilakukan oleh 27 siswa kelas VIII SMP Negeri 11 Lubuklinggau. Analisis data untuk kevalidan kepraktisan masing-masing dijabarkan pada Tabel 1 dan Tabel 2.
Tabel 1. Kriteria valid.

\begin{tabular}{cc}
\hline Interval Rerata Skor & Kategori \\
\hline $\mathrm{x}>\bar{x}_{i}+1,8 \mathrm{x} \mathrm{sb}_{\mathrm{i}}$ & $\begin{array}{c}\text { Sangat } \\
\text { valid }\end{array}$ \\
$\bar{x}_{i}+0,6 \mathrm{x} \mathrm{sb}_{\mathrm{i}}<\mathrm{x} \leq \bar{x}_{i}+1,8 \mathrm{x} \mathrm{sb}_{\mathrm{i}}$ & Valid \\
$\bar{x}_{i}-1,8 \mathrm{x} \mathrm{sb}_{\mathrm{i}}<\mathrm{x} \leq \bar{x}_{i}-0,6 \mathrm{x} \mathrm{sb}_{\mathrm{i}}$ & Kurang \\
valid \\
$\mathrm{x} \leq \bar{x}_{i}-1,8 \mathrm{x} \mathrm{sb}_{\mathrm{i}}$ & $\begin{array}{c}\text { Sangat } \\
\text { kurang } \\
\text { valid }\end{array}$ \\
\hline \multicolumn{2}{c}{ Widoyoko (2009) }
\end{tabular}

Tabel 2. Kriteria praktis.

\begin{tabular}{cc}
\hline Interval Rerata Skor & Kategori \\
\hline $\mathrm{x}>\bar{x}_{i}+1,8 \mathrm{x} \mathrm{sb}_{\mathrm{i}}$ & $\begin{array}{c}\text { Sangat } \\
\text { praktis }\end{array}$ \\
$\bar{x}_{i}+0,6 \mathrm{x} \mathrm{sb}_{\mathrm{i}}<\mathrm{x} \leq \bar{x}_{i}+1,8 \mathrm{x} \mathrm{sb}_{\mathrm{i}}$ & Praktis \\
$\bar{x}_{i}-1,8 \mathrm{x} \mathrm{sb}_{\mathrm{i}}<\mathrm{x} \leq \bar{x}_{i}-0,6 \mathrm{x} \mathrm{sb}_{\mathrm{i}}$ & $\begin{array}{c}\text { Kurang } \\
\text { praktis }\end{array}$ \\
$\mathrm{x} \leq \bar{x}_{i}-1,8 \mathrm{x} \mathrm{sb}_{\mathrm{i}}$ & $\begin{array}{c}\text { Sangat } \\
\text { kurang } \\
\text { praktis }\end{array}$ \\
\hline \multicolumn{2}{c}{ Widoyoko (2009) }
\end{tabular}

\section{HASIL PENELITIAN DAN PEMBAHASAN}

Tahap Analysis; tahap ini meliputi analisis kebutuhan, analisis kompetensi dan analisis instruksional siswa. Hasil dari analisis kebutuhan yang dilakukan pada tanggal 7-12 Januari 2019 menunjukkan bahwa guru masih mengalami kesulitan dalam menemukan LKS yang memfasilitasi kemampuan pemecahan masalah. Hal ini berdampak pada kualitas pembelajaran yang didapatkan oleh siswa. Berdasarkan hasil pengamatan, diketahui bahwa penggunaan LKS dalam proses pembelajaran matematika sangat mempengaruhi prestasi akademik siswa. Tuntutan dari kurikulum 2013 yang bertujuan untuk mendorong siswa agar lebih baik dalam melakukan observasi, bertanya dan mengkomunikasikan 
DOI: https://doi.org/10.24127/ajpm.v8i3.2360

(mempresentasikan) yang mereka peroleh atau mereka ketahui setelah menerima materi pembelajaran diperlukan sebuah LKS berbasis model pembelajaran yang dapat membantu proses pembelajaran, menyajikan permasalahan yang harus dipecahkan bersama sehingga terciptanya kegiatan pembelajaran yang mampu melatih kemampuan memecahkan masalah dan dapat meningkatkan kerjasama dan tanggung jawab siswa dalam menemukan konsep.

Tahap Design; hasil dari tahap analisis dijadikan sebagai dasar dalam membuat desain LKS. Adapun yang harus dilakukan dalam tahap desain yaitu penyusunan rancangan LKS dan membuat instrumen penelitian.

Tahap Development; setelah perancang menghasilkan rancangan awal LKS (Draf I LKS) kemudian divalidasi yang dilakukan oleh validator (ahli bahasa, ahli materi dan ahli media) yaitu penilaian LKS pada setiap aspek yang ditanyakan pada lembar penilaian dilihat dari komponen kelayakan isi, kelayakan penyajian, aspek penilaian Problem Based Learning, kelayakan bahasa, dan kelayakan kegrafikan. Selain itu, dalam validasi ini validator memberi komentar dan saran untuk perbaikan LKS yang disajikan pada Tabel 3. Selanjutnya hasil penilaian dan saran digunakan untuk revisi LKS.

Tabel 3. Komentar dan saran dari ketiga validator

\begin{tabular}{ll}
\hline \multicolumn{1}{c}{ Validator } & \multicolumn{1}{c}{ Komentar dan Saran } \\
\hline Ahli Bahasa & Perbaiki beberapa kalimat dan kata yang salah pengetikan \\
Ahli Materi & Perbaiki soal dan kesimpulan atau refleksi. \\
Ahli Media & 1. Tambahkan nomor urut pada peta konsep dan petunjuk penggunaan. \\
& 2. Perhatikan resolusi gambar (terdapat gambar yang tidak jelas). \\
& 3. Tambahkan keterangan gambar atau ilustrasi. \\
& 4. Secara keseluruhan sudah baik dan dapat digunakan dengan revisi. \\
\hline
\end{tabular}

Secara umum, penilaian terhadap rancangan LKS oleh para ahli adalah "LKS dapat digunakan dengan revisi sesuai saran" dan hasil perhitungan validitas dari semua para ahli adalah "valid" dengan rata-rata skor 3,08.

Pelaksanaa uji coba kelompok kecil terdiri dari 6 siswa yang diambil secara heterogen, yang memiliki tingkat kemampuan rendah, sedang dan tinggi. Sebelum diberikan angket kepraktisan siswa, enam orang siswa diminta untuk mempelajari LKS terlebih dahulu secara mandiri dalam waktu 30 menit. Setelah itu masing-masing siswa diberikan angket kepraktisan yang terdiri dari 20 pernyataan yang bertujuan untuk mengetahui respon kepraktisan siswa terhadap LKS yang dikembangkan.
Berdasarkan hasil perhitungan angket kepraktisan uji coba kelompok kecil, yang diperoleh 6 siswa yang menunjukkan respon positif terhadap LKS berbasis Problem Based Learning dengan memperoleh skor rata-rata sebesar 3,36. Hasil dari penilaian angket kepraktisan uji coba kelompok kecil dikategorikan Praktis dan menunjukkan tidak perlu adanya revisi terhadap LKS berbasis PBL yang dikembangkan. Dengan demikian, LKS yang dikembangkan dapat digunakan pada tahap uji coba kelompok besar.

Tahap Implementation; Uji coba kelompok besar dilakukan ada siswa kelas VIII.2 SMP Negeri 11 Lubuklinggau yang berjumlah 27 siswa. Dalam uji coba ini, peneliti bertindak sebagai fasilitator. Selama proses 
pembelajaran, peneliti membimbing siswa dengan panduan LKS dan RPP yang telah disiapkan. Perangkat pembelajaran berupa RPP dan LKS berbasis Problem Based Learning. Waktu pelaksanaa uji coba ini dilaksanakan selama satu kali pertemuan untuk melihat respon siswa terhadap LKS yang dikembangkan. Terdapat kendala dalam uji kelompok besar yaitu beberapa siswa mengalami kesulitan ketika menyelesaikan operasi hitung untuk angka yang tergolong besar, kurangnya rasa percaya diri ketika akan menjawab masalah yang disajikan.
Setelah siswa selesai mengikuti proses pembelajaran, siswa diminta untuk mengisi angket kepraktisan siswa yang terdiri dari 20 butir pernyataan. Angket kepraktisan siswa diberikan untuk mengetahui respon kepraktisan siswa terhadap LKS yang dikembangkan. Berdasarkan hasil perhitungan angket uji coba kelompok besar memperoleh skor rata-rata sebesar 3,40. Dengan demikian hasil perhitungan angket kepraktisan siswa terhadap LKS yang dikembangkan dikategorikan Praktis disajikan pada Tabel 4.

Tabel 4. Hasil analisis angket kepraktisan siswa

\begin{tabular}{|c|c|c|c|}
\hline No & Pernyataan & Jumlah Siswa & $\begin{array}{l}\text { Skor yang } \\
\text { diperoleh }\end{array}$ \\
\hline 1 & $\begin{array}{l}\text { Tampilan atau gambar LKS membuat saya senang dalam } \\
\text { mempelajari materi }\end{array}$ & 27 & 99 \\
\hline 2 & $\begin{array}{l}\text { Saya dapat mengetahui isi apa saja yang akan saya } \\
\text { pelajari pada LKS ini dari daftar isi }\end{array}$ & 27 & 89 \\
\hline 3 & $\begin{array}{l}\text { Gambar maupun ilustrasi dalam LKS ini bagi saya tidak } \\
\text { membingungkan }\end{array}$ & 27 & 95 \\
\hline 4 & $\begin{array}{l}\text { Dalam menjelaskan suatu konsep LKS ini menggunakan } \\
\text { ilustrasi masalah nyata }\end{array}$ & 27 & 88 \\
\hline 5 & $\begin{array}{l}\text { Masalah, ilustrasi, maupun uji kompetensi pada LKS ini } \\
\text { memuat masalah yang berkaitan dengan kehidupan } \\
\text { sehari-hari }\end{array}$ & 27 & 92 \\
\hline 6 & $\begin{array}{l}\text { Saya dapat menghubungkan isi LKS ini dengan hal-hal } \\
\text { lain yang pernah saya lihat/ketahui yang berkaitan } \\
\text { dengan kehidupan sehari-hari }\end{array}$ & 27 & 86 \\
\hline 7 & $\begin{array}{l}\text { Kegiatan yang ada pada LKS membuat saya mudah } \\
\text { memahami materi }\end{array}$ & 27 & 88 \\
\hline 8 & $\begin{array}{l}\text { Dengan LKS, saya merasa mudah untuk mengingat } \\
\text { konsep-konsep materi pelajaran }\end{array}$ & 27 & 94 \\
\hline 9 & $\begin{array}{l}\text { Adanya masalah yang mengawali kegiatan dalam LKS } \\
\text { membantu saya memahami materi Bangun Ruang Sisi } \\
\text { datar }\end{array}$ & 27 & 96 \\
\hline 10 & Tampilan atau gambar LKS ini membosankan & 27 & 101 \\
\hline 11 & Bahas yang digunakan dalam LKS ini mudah dipahami & 27 & 83 \\
\hline 12 & Saya senang pembelajaran menggunakan LKS ini & 27 & 87 \\
\hline 13 & $\begin{array}{l}\text { Saya lebih paham jika rumus matematika diperoleh } \\
\text { dengan cara menemukan sendiri }\end{array}$ & 27 & 88 \\
\hline 14 & $\begin{array}{l}\text { Pembelajaran menggunakan LKS ini terlalu berbelit } \\
\text { sehingga membuat saya bingung memahami materi }\end{array}$ & 27 & 92 \\
\hline 15 & $\begin{array}{l}\text { Kegiatan yang ada dalam LKS membuat saya mudah } \\
\text { memahami materi }\end{array}$ & 27 & 90 \\
\hline
\end{tabular}


DOI: https://doi.org/10.24127/ajpm.v8i3.2360

16 Perintah dalam LKS membuat saya bingung

17 Kombinasi warna yang digunakan dalam LKS ini meningkatkan semangat saya belajar matematika

18 Setelah menggunakan LKS ini, saya bersemangat untuk belajar bangun ruang sisi datar

19 Penggunaan symbol dan istilah dalam LKS ini mudah dipahami

20 LKS ini dapat memotivasi dan menambah pengetahuan saya untuk belajar bangun ruang sisi datar
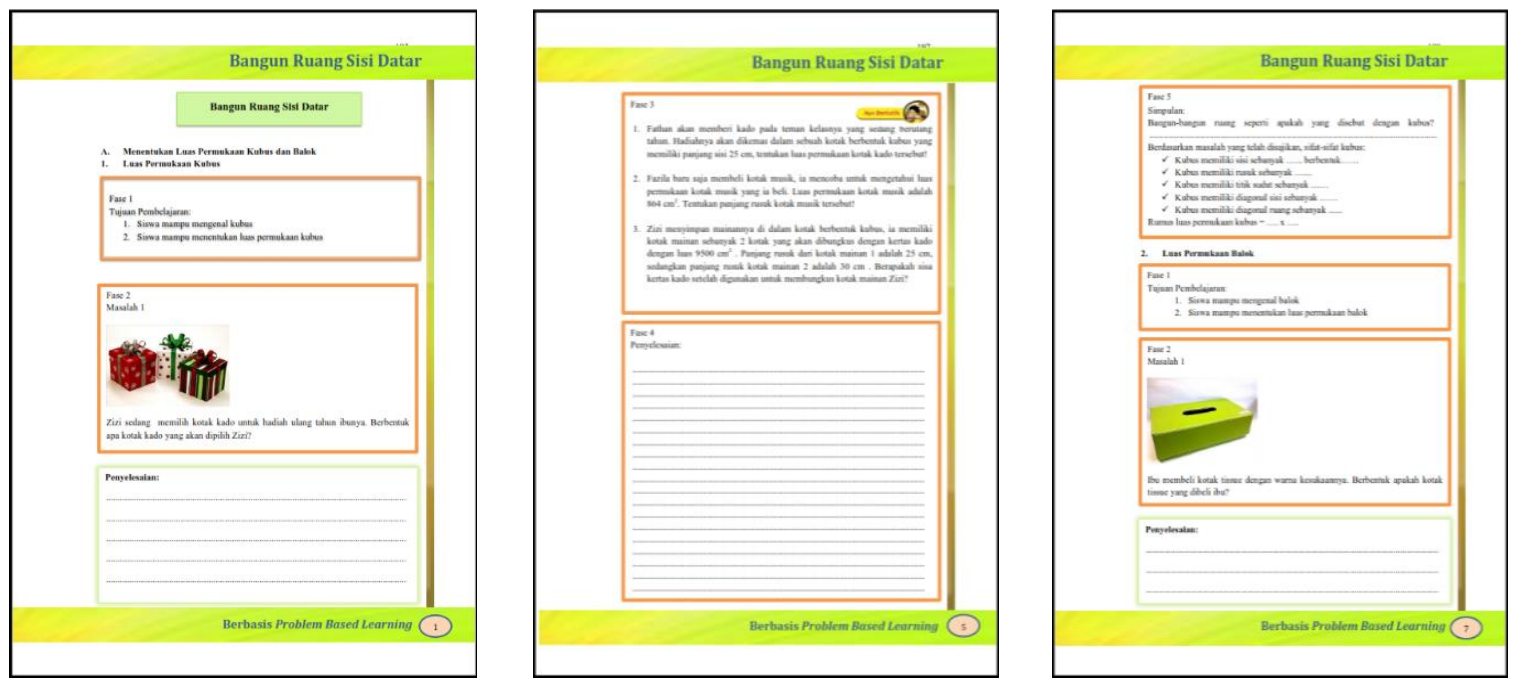

Gambar 1. Hasil produk LKS berdasarkan tahapan $P B L$

Berdasarkan pada Gambar 1, dapat dilihat bahwa LKS yang dikembangkan memuat setiap tahapan dari Problem Based Learning, sehingga setiap tahapan pada $P B L$ fase 1 adalah penyajian tujuan pembelajaran, fase 2 adalah penyajian masalah secara kontekstual, fase 3 adalah latihan soal, fase 4 mengenai penyelesaian dari permasalahan, dan fase yang terakhir adalah simpulan.

Tahap Evaluation; pada tahap evaluasi, data dari analisis angket kepraktisan siswa kemudian dianalisis. Analisis angket kepraktisan siswa bertujuan untuk mengetahui respon kepraktisan siswa terhadap LKS yang dikembangkan dan untuk mengetahui kepraktisan LKS yang dikembangkan. Berdasarkan uraian di atas, dapat disimpulkan bahwa kualitas Lembar Kerja Siswa berbasis Problem Based Learning pada Materi Bangun Ruang Sisi Datar Kelas VIII SMP Negeri 11 Lubuklinggau ditinjau dari aspek kevalidan dan kepraktisan dapat dikategorikan valid dan praktis.

Penelitian ini memberikan implikasi yaitu dapat menyediakan lingkungan pembelajaran matematika 
yang biasanya terbatas di dalam kelas menjadi pembelajaran di luar kelas disajikan bersifat terbuka, dapat memfasilitasi peserta didik untuk mampu memahami konsep matematika dengan pengetahuan awal yang sudah mereka ketahui karena melakukan lingkungan siswa sendiri, dan dapat menyediakan lingkungan pembelajaran yang menciptakan motivasi yang baik dan menyenangkan serta bebas dari anggapan bahwa matematika itu sulit.

Proses penelitian ini sejalan dengan penelitian Zulfah (2017), hanya saja model pengembangan yang dipakai berbeda dari penelitian ini. Zulfah (2017) telah mengembangkan LKPD berbasis PBL untuk materi matematika semester 1 SMP kelas VIII. Hanya saja LKPD yang dikembangkan baru terbatas pada tahapan preliminary research. Hal ini menunjukkan bahwa penelitian ini merupakan penyempurnaan dari beberapa hasil penelitian sebelumnya yang berkaitan dengan pengembangan LKS berbasis PBL.

\section{KESIMPULAN DAN SARAN}

Berdasarkan hasil penelitian dapat diambil kesimpulan bahwa LKS berbasis PBL pada materi bangun ruang sisi datar yang dikembangkan dikatagorikan valid dan praktis untuk proses pembelajaran.

Adapun saran untuk penelitian selanjutnya hendaknya dapat mengembangkan LKS pada materi yang lebih luas lagi dan penelitian selanjutnya dapat mencapai tahap melihat efektivitas pembelajaran dengan menggunakan LKS yang telah dikembangkan.

\section{DAFTAR PUSTAKA}

Alawiyah, F. (2013). Peran Guru dalam Kurikulum 2013. Jurnal Aspirasi, 4(1), 65-74.

Anwar, R. (2014). Hal-Hal Yang Mendasari Penerapan Kurikulum 2013. Jurnal Humaniora, 5(1), 97-106.

Ermi, N. (2017). Penggunaan Media Lembar Kerja Siswa (LKS) Dalam Meningkatkan Hasil Belajar Sosiologi Siswa Kelas XI SMAN 15 Pekanbaru. Jurnal Pendidikan, 37-45.

Ernawati, A., Ibrahim, M. M., \& Afiif, A. (2017). Pengembangan Lembar Kerja Siswa Berbasis Multiple Intelligences Pada Pokok Bahasan Substansi Genetika Kelas XII IPA SMA Negeri 16 Makassar. Jurnal Biotek, 5(2), 1-18.

Jayanti, M., \& Wiratomo, Y. (2017). Perancangan Media Siap UN Matematika SMP Berbasis Android. Jurnal SAP, 2(1), 2232.

Nasution, A. (2016). Pengembangan Modul Matematika Berbasis Masalah Untuk Meningkatkan Kemampuan Pemecahan Masalah Matematika Siswa. Jurnal Pendidikan dan Kependidikan, 1(1), 47-63.

Saraswati, A. M., \& Nuryani, C. E. (2018). Pengembangan Lembar Kerja Siswa (LKS) Berdasarkan Model Pembelajaran Guided Discovery. Jurnal Aksioma, 9(1), 97-112.

Setiawan, A., \& Wariin B, I. (2017). Desain Bahan Ajar Yang Berorientasi Pada Pada Model Pembelajaran Student Team Achievement Division Untuk Capaian Pembelajaran Pada Ranah Pemahaman Siswa Pada 
DOI: https://doi.org/10.24127/ajpm.v8i3.2360

Mata Pelajaran IPS Kelas VII SMP Negeri 1 Plered Kabupaten Cirebon. Jurnal Edunomic, 5(1), 17-32.

Sofyan, H., \& Komariah, K. (2016). Pembelajaran Problem Based Learning Dalam Implementasi Kurikulum 2013 di SMK. Jurnal Pendidikan Vokasi, 6(3), 260271.

Wahyuni, R., \& Efuansyah. (2018). Model Pembelajaran Missouri Mathematics Project (MMP) Menggunakan Strategi Think Talk Wite (TTW) terhadap Kemampuan Berpikir Kritis dan Kemampuan Pemecahan Masalah. JNPM (Jurnal Nasional Pendidikan Matematika), 2(1), 24-36.

Wasonowati, R. R., Redjeki, T., \& Ariani, S. R. (2014). Penerapan Model Problem Based Learning (PBL) Pada Pembelajaran Hukum-hukum Dasar Kimia Ditinjau Dari Aktivitas Dan Hasil Belajar Siswa Kelas X IPA SMA Negeri 2 Surakarta Tahun Pelajaran 2013/2014. Jurnal Pendidikan Kimia, 3(3), 66-75.

Widoyoko, E. P. (2009). Evaluasi Program Pembelajaran. Yogyakarta: Pustaka Belajar.

Zulfah. (2017). Tahap Prelimary Research Pengembangan LKPD Berbasis PBL Untuk Materi Matematika Semester 1 Kelas VIII SMP. Jurnal Cendekia: Pendidikan Matematika, 1(2), 112. 